\title{
Emotional burnout as a result of professional stress in the work of managers (in the context of self-actualization)
}

\author{
Elena Voitenko \\ University of the State Fiscal Service of Ukraine
}

\begin{abstract}
The research is aimed at expanding the scientific understanding of the psychological characteristics of professional stress, the causes of its occurrence, as well as the effects of stressors in the manager's work. The article attempts to correlate the semantic fields of the concepts professional stress and emotional burnout. A definition and characterization of emotional burnout syndrome as a consequence of chronic stress is provided. The specificity of the manifestation of emotional burnout in the totality of the influence of objective and subjective factors in the activity of managers is presented. The content of the concept of self-actualization is defined. The expediency of applying a positively oriented (existentialhumanistic) approach in the search for psychological resources of coping with emotional burnout is substantiated. The study provides a theoretical and methodological basis for the development of measures for effective prevention and psychological correction of emotional burnout syndrome.
\end{abstract}

Keywords:

Professional Stress, Emotional Burnout, Self-Actualization

\section{Introduction}

In a market economy and fierce competition, the professional activity of the manager is full of many economic, organizational and socio-psychological stresses. Therefore, nowadays finding ways to activate the human factor within the organization and taking into account the social and psychological characteristics of staff is a condition for improving the effectiveness of any organization.

Correspondence:

evoytenko73@gmail.com 
The profession of manager belongs to the most emotionally intense types of professional activity (Ronginskaya, 2002). This profession requires a huge amount of energy, physical strength and mental health from the individual. The professional activity of a manager is constantly connected with intensive communication, purposeful perception of partners and influence on them. The manager has to supporte of various aspects of communication emotionally (to resolve conflict situations, to be attentive, to interpret information quickly) (Boyko, 1996). Managers suffer from chronic occupational stress, which leads to poor quality of work, loss of interest in it, emotional burnout (Vodopyanova, 2000). Occupational stress can have a significant impact on mental and physical health. A constructive solution to this problem can be mastering effective ways of dealing with emotional complications. (Skaalvik \& Skaalvik, 2015; Folkman, 2013). Therefore, the study of the specifics and consequences of occupational stress in the activities of the modern manager, as well as the study of psychological resources coping with emotional burnout is particularly important. One of the factors of coping with burnout can be self-actualization, which is associated with personal maturity, personal autonomy, self-management, without which successful professional activity is impossible.

The purpose of the article is to analyze the concept of "emotional burnout" as a consequence of occupational stress, taking into account the specific activity of managers; expand scientific and practical understanding of the effects of occupational stress and psychological resources of coping with emotional burnout through the analysis of the relationship between emotional burnout and selfactualization of the individual.

\section{Literature Review}

The study of the development of stress in the workplace is highlighted as the most important scientific problem in connection with its impact on the ability to work, productivity and quality of work, health status of the employee.

A review of the literature on this issue shows that there is no universally accepted concept of occupational stress. There are various theories and models that complement and develop each other (Greenberg, 2004; Bohan, 2008; Bodrov, 2006).

There are three main approaches to analyzing professional stress.

Representatives of the first approach argue that occupational stress arises from inconsistencies (or incompatibilities) of the requirements of the work environment and the individual resources of the working person. And this creates a potential threat to the success of work behavior, health and wellbeing (Greenberg, 2004).

In the second approach, occupational stress is studied as a direct consequence of the development of cognitive concepts of stress (Bodrov, 2006). The founder of this view of the nature of psychological stress was R. Lazarus (1974). He first shifted the focus of attention from the traditional study of mechanisms of homeostatic regulation and stages of adaptation to the analysis of individual psychological factors that cause the development of stress. Central to this analysis was the subjective significance of the situation in which the person is acting, and the means (or strategies of behavior) by which that person tries to overcome the difficulty. Studies of representatives of this approach trace the role of individual-psychological factors in the processes of formation of occupational stress syndromes, but don't reveal their real impact on the effectiveness of activities.

A detailed analysis of the regulatory mechanisms that ensure the success of human behavior in the current circumstances is the content of the third independent approach to the study of occupational stress.

The main subject of study of the third approach is the detailing of ideas about the change of mechanisms of regulation of activity under the influence of various factors. This approach allows to trace the development of the negative effects of stress from the onset of stress through the accumulation of chronic effects to the formation of persistent pathological changes (Orel, 2005). 
Thus, the first two approaches help optimize work and eliminate objective sources of stress. The third approach in the study of occupational stress allows to individualize the means of providing psychological help, based on knowledge of conditions that need correction and prevention. It is this approach that identifies a lack of individual ways and skills in coping with stressful situations, which can be offset during special training.

Stress is also considered as a "superadaptive syndrome" that is able not only to provide stability of the individual, but also to contribute self-development, self-realization. A person who is unable to exercise their capabilities is doomed to chronic, destructive stress (or distress) (Bohan, 2008).

Summarizing the empirical facts of foreign and domestic research shows that prolonged occupational stress can cause professional deformity of the individual in the form of emotional burnout. These are changes that reduce the adaptability of staff and the effectiveness of their work: a decrease in the overall mental stability of the body, the appearance of feeling dissatisfied with the results of their activities, the tendency to refuse to perform tasks in situations of high demands or failures (Boyko, 1996; Maslach, 2003).

The term "emotional burnout" is most often used to describe the state of mental overload in the social professions. This syndrome arises in situations of intensive professional communication under the influence of many external and internal factors (Boyko, 1996; Grishina, 1997; Maslach, 2003; Orel, 2005). It manifests as a "suppression" of emotions, the disappearance of the severity of feelings and emotions, increasing the number of conflicts with partners in communication, indifference and detachment from the experiences of another person, loss of sense of value of life, loss of belief in their own strength, etc.

In ordering modern approaches to the study of emotional burnout, we sought to identify the specific basic settings or research paradigms inherent in each approach (Table 1).

The ordering of scientific data on emotional burnout has identified two main types of its models. Models of the first type consider burnout as a state of physical, emotional and cognitive exhaustion caused by prolonged stay in emotionally distressed situations (Bodrov, 2006; Shirom, 1989). Process models analyze burnout as a dynamic process of growing emotional exhaustion that has certain phases (Vodopyanova, 2000; Maslach, 2003).

Much research has been devoted to the phenomenon of "burn-out" of social workers: managers, sales staff, teachers (Babich, 2007; Vodopyanova, 2000; Ronginska, 2002). It is argued that representatives of the social professions are particularly vulnerable to burnout, since they are in a state where they need to constantly control their emotions, take responsibility, and feel uncertain when working with other people.

Table 1: Basic approaches to understanding of emotional burnout syndrome

\begin{tabular}{llrl}
\hline № & Author & Year & The content of the concept \\
\hline 1 & H. Freudenberger & 1974 & $\begin{array}{l}\text { Chronic fatigue, depression and frustration when an individual is forced to engage in a } \\
\text { business that does not satisfy his ambitions and does not produce the expected result }\end{array}$ \\
\hline 2 & A. Shirom & 1989 & Response to chronic stress \\
\hline 3 & T. Formanyuk & 1994 & Professional maladaptation \\
\hline 4 & N. Grishina & 1997 & Physical, mental or emotional exhaustion, loss of motivation and responsibility \\
\hline 5 & T. Ronginskaya & 2002 & $\begin{array}{l}\text { Protective reaction in the form of saving emotions, deformation of personality; } \\
\text { functional stereotype that allows a person to spend energy resources economically }\end{array}$ \\
\hline 6 & C. Maslach & 2003 & $\begin{array}{l}\text { Syndrome of physical, emotional exhaustion that arises from the stress caused by } \\
\text { interpersonal communication and consists in the development of negative self-esteem, } \\
\text { negative attitude to work, loss of understanding and compassion for clients }\end{array}$ \\
\hline 7 & V. Boyko & 2004 & Form of professional deformation of personality \\
\hline 8 & L. Kulikov & 2004 & Occupational stress, which takes the form of a protracted course \\
\hline 9 & V. Orel & 2005 & Systemic phenomenon \\
\hline 10 & A. Langle & 2007 & Manifestation of the non-existential attitude to life \\
\hline 11 & L. Kitaev-Smyk & 2008 & Sickness of communication, a consequence of mental fatigue \\
\hline
\end{tabular}


Based on the analysis of existing definitions of burnout, its relation to emotional labor (regulation and expression of emotional states) is established. Emotional work is considered to be a predictor of burnout in the social professions (Vodopyanova, 2000; Babich, 2007).

The phenomenon of burnout due to its complexity and ambiguity has many correlates among different internal personality traits, states and qualities, external factors. External (situational and organizational) factors of burnout and internal, personal factors of burnout are widely studied. Among the internal factors of great importance are the features of the value-semantic sphere (values, level of self-realization) (Babich, 2007; Kitaev-Smyk, 2008).

Researchers are actively exploring the various ways and mechanisms of person's adaptation to the demands of professional activity, which is directly related to the problem of stress (Boyko, 1999; Kurapova, 2009; Ronginskaya, 2002).

Of particular interest in the aspect of coping with burnout is the process of self-actualization of the individual. Some authors consider it a system-forming personal resource coping with burnout (O. Babich, 2007), others study it as a factor in resistance to burnout (Kurapova, 2009; Malanowski \& Wood, 1984).

The relationship of self-actualization with burnout in teachers is being actively researched (Babich, 2007; Kurapova, 2009). It is noted that self-actualization is one of the most significant system-forming personal resources of burnout prevention in teachers.

Despite the large amount of research on emotional burnout and self-actualization, the problem of managers' self-actualization in the aspect of regulating emotional burnout remains poorly understood. The importance of internal determination in the regulation of states of managers, self-actualization as a factor of full functioning of the personality and coping with emotional burnout and determined the purpose of this study.

\section{Methodology.}

The subject, purpose and objectives of the study have determined the usage of the complex of theoretical methods, which include theoretical analysis, systematization and synthesis of data of scientific publications by leading experts in the field of social psychology and psychology of management without any time constraints.

\section{Discussion}

Criteria for stress are not only physiological reactions but also mental states and changes in activity. This idea dominates the scientific literature. And the main criterion is the measure of change in the functional level of activity.

The papers devoted to this issue focus on the peculiarities of behavior in stress, depending on the degree of significance of the situation, psychological characteristics of the individual. These are the attitude of the person to the difficulties in work, successes and failures, the ratio of the level of his or her aspirations and real opportunities, the level of self-confidence, the personality orientation, etc. Particular role in the occurrence of psychological stress belongs to intellectual activity and motivation (Greenberg, 2004).

The most popular in the literature is the understanding of occupational stress as a complex phenomenon, which is expressed in mental and physical reactions to stressful situations in a person's professional activity, when requirements to him don 't correspond to his level of knowledge and skills. The professional activity of managers is quite stressful due to the richness of communication, the need to solve problematic situations in the short term, the need to obey the requirements, standards of the organization, to maintain positive contact, regardless of personal attitude (Ronginskaya, 2002). In the case when the manager doesn't have enough personal resources coping with professional stressors, a complex negative psychophysiological state - emotional burnout can be formed. In the most general 
form, emotional burnout refers to a systemic, complex negative psychophysiological state, which includes stressful manifestations, protective reaction in the form of saving emotions, changes in attitude to oneself, others and profession, existential manifestations (loss of meaning, values of professional activity).

Maslach (2003) treats professional burnout as a physical and emotional exhaustion syndrome characterized by a negative attitude towards work, low self-esteem, lack of understanding of clients and loss of compassion for them.

According to the model of Maslach, emotional (professional) burnout is considered as a threecomponent structure and includes emotional exhaustion, depersonalization and reduction of personal achievements. Emotional exhaustion is manifested in feelings of emotional overstrain and in a sense of devastation, exhaustion of one's own emotional resources. At this stage, the following symptoms may occur: headaches, malaise, colds. Depersonalization tends to develop a negative, cynical attitude toward recipients (colleagues, clients, etc.). This stage is characterized by: inadequate selective emotional response, emotional and moral disorientation, distancing (expanding the sphere of saving emotions). The reduction of personal achievements is manifested in the form of a decrease in the sense of competence in work, dissatisfaction with oneself, a decrease in the value of one's activity, a decrease in the level of self-esteem both in personal and professional terms, the appearance of a sense of one's own incapacity, indifference to work. At this stage, psychosomatic and autonomic disorders appear.

The relation and distinction between the concepts of "stress" and "emotional burnout" are the cause of active debate among scientists.

According to Maslach (2003), professional burnout is an emotional exhaustion that arises against the stress of interpersonal interaction. It's appearance indicates that the individual is also prone to other stressors. Professionals characterized by the presence of emotional burnout are in most cases unable to overcome the emotional stress associated with work. In Boyko's (1996) concept, professional burnout is considered as a distress or a stage of exhaustion, a stage of general adaptation syndrome. Kulikov (2004) views burnout as occupational stress, which takes the form of a protracted course. Grishina (1997) proves that burnout should be studied as a special condition of a person, which is a consequence of professional stress.

In our opinion, emotional burnout is not the same as stress. Burnout is a more complex condition than stress, what affect on the value-semantic sphere as an existential phenomenon, closely linked to the content of the profession and life. It's known that many specialists-managers with extensive work experience, for many years being in stressful conditions, continue to work productively, realizing themselves in the activity. According to Maslach, Schaufeli, and Leiter (2001), the resistance of a person to burnout is determined by involvement in the profession, which is based on the characteristics of the value-semantic sphere of personality.

Researchers note the important role of internal determination in self-regulation of personality (Babich, 2007; Skaalvik, \& Skaalvik, 2015). It is known that different individuals respond differently to the same stressor. According to Dikaya (2003), the type of response and direction of behavior depends on the individual characteristics of the individual and, in particular, on his individual psychological resources of psychological coping.

\section{One of the factors in preventing burnout can be self-actualization.}

The concept of self-actualization arose within the humanistic-existential approach in psychology. Rogers (1994) views self-actualization as a process of realizing a person's potential for becoming a fully functioning personality. According to Maslow (1999), self-actualization is the desire of the person for self-realization, for the actualization of laid potentials, the desire for identity, when a 
person should be who he can be. At the heart of physical, mental health is the realization of the personality of the psychological potential, maintaining the balance between desires and opportunities.

According to Gozman (1995), self-actualization includes the full development of creative, spiritual potential, maximum realization of opportunities, adequate perception of others, wealth of the emotional sphere and spiritual life, mental health and morality. Dikaya (2003) believes that selfrealization is characterized by productivity: the growth of mental and personal activity, the transition to a qualitatively new level of activity and satisfaction. We consider self-actualization as a set of personality traits that make up the internal potential that determine the personality's resistance to negative psychophysiological states in professional activity.

Study of teachers' emotional burnout shows that burnout syndrome is inversely correlated with features of self-actualization (Malanowski, \& Wood, 1984). It is noted that self-actualization is one of the most significant backbone personality resources coping with burnout.

However, the role of self-actualization and its individual components in regulating emotional burnout of managers over a long period is still insufficiently studied, there is no clear answer to the question about the mutual influence of burnout and stress, it is not determined what features of selfactualization contribute to or hinder the development of burnout. There is evidence that the subjective image of professional development and self-realization of the individual, personal ambitions can also become determinants of occupational stress, which is a complex phenomenon by causal conditionality, and arises not only in response to difficulties and special requirements of the profession. According to Bohan (2008), self-realization of the person can also cause stress as it is accompanied by the correction of a way of life, change of perception of the image of the world, etc., which, sometimes, situationally deprives the person of resources. On the one hand, people strive for stability, on the other - for changes that inevitably cause stressful states, accompanied by the experiences of anxiety, self-aggression, apathy, depression and similar negative emotions.

\section{Conclusions and Future Study}

1.Professional stress is a factor that has a negative impact on the performance, productivity and quality of work, health of the employee. They are capable of destroying human resources from the inside, reducing the efficiency, mobility, provoking the negative dynamics of strategic development of the organization. A high level of professional stress leads to an increase in non-constructive tension, adversely affects the health of staff, their loyalty to the organization, leads to staff turnover.

2. The professional activity of managers is quite stressful due to the richness of communication, the need to solve problematic situations in the short term, the need to obey the requirements, standards of the organization, to maintain positive contact, regardless of personal attitude. Insufficient development of adaptive abilities to stress, inability to regulate their mental and psychophysiological health can lead to such professional deformations as emotional burnout syndrome.

3. Burnout is a state of emotional, mental and physical exhaustion caused by excessive and prolonged stress. This happens when a person feels depressed, emotionally exhausted, unable to meet their daily needs, which causes a loss of interest and motivation for the work being done. Burnout reduces the productivity of a person's activity, adversely affects his psycho-emotional state. Based on the analysis and systematization of the scientific literature on burnout, its three main components are identified: emotional and/or physical exhaustion, reduced productivity, and excessive depersonalization.

4. Of special interest in the aspect of coping with burnout is the process of personality selfactualization, which some authors consider as a system-forming personal resource for overcoming burnout, others as a factor of resistance to burnout. However, the role of self-actualization and its individual components in regulating the professional burnout of managers over a long period is still poorly understood. There is no clear answer to the question about the mutual influence of burnout, 
stress, it is not defined what features of self-actualization contribute to or hinder the development of burnout.

Studying the features and individual components of the self-actualization of the manager's personality will give an opportunity to understand the role of internal determination in the formation of managers' resistance to the development of emotional burnout, as well as allow to develop measures of effective prevention and psychological correction of the emotional burnout syndrome.

\section{References}

Бабич, О.И. (2007). Личностные ресурсы преодоления синдрома профессионального выгорания педагогов: дис. ... канд. психол. наук. Хабаровск, 184 с.

Бодров, В.А. (2006). Психологический стресс: развитие и преодоление. М.: PerSe,. 528 с.

Бойко, В.В. (1996). Синдром «эмоционального выгорания» в профессиональном общении / В.В. Бойко. - М.: Наука, $384 \mathrm{c}$.

Бойко, В.В. (2004) Энергия эмоций. - СПб: Питер, 474 с.

Бохан, Т.Г. (2008). Стресс и стрессоустойчивость: опыт культурно-исторического исследования / Т. Г. Бохан. Томск: Изд-во «Иван Федоров», 267 с.

Водопьянова, Н. Е. (2000). Синдром психического выгорания в коммуникативных профессиях / Н. Е. Водопьянова // Психология здоров'я / под. ред. Г. С. Никифорова. - СПб., С. 443-463.

Гозман, Л.Я. (1995). Самоактуализация личности и проблема её измерения / Л.Я. Гозман, М.В. Кроз, М.В. Латинская // Российское педагогическое агентство: учебн. пособ. - М., Разд. 1. - С. 3-6.

Гринберг, Дж. С. (2004). Управление стрессом. СПб.: Питер, 496 с.

Гришина, Н. В. (1997). Помогающие отношения: профессиональные и экзистенциональные проблемы // Психологические проблемы самореализации личности. - СПб.:Изд-во Санкт-Петерб. Ун-та, С. 143-156.

Дикая, Л.Г. (2003). Психическая саморегуляция функционального состояния человека (системно-деятельностный подход). М.: Изд-во Института психологии РАН, 318 с.

Китаев-Смык Л.А. (2008). Выгорание персонала. Выгорание личности. Выгорание души // Психопедагогика в правоохранительных органах. № 2 (33). С. 41-50.

Куликов, Л.В. (2004). Психогигиена личности. Вопросы психологической устойчивости и психопрофилактики. СПб: Питер, 464 с.

Курапова, И.А. (2009). Нравственно-ценностная регуляция эмоционального выгорания в профессиональной деятельности (на примере педагогов средней и высшей школы): дисс. на соискание учен. степени канд. психол. наук. - М., 232 с.

Lasarus, R.S. (1974). Psychological stress and coping in adaptation and illness, International Journal of Psychiatry in Medicine, 5(4); 321-333.

Лэнгле, А. (2007). Эмоции и экзистенция. - Харьков: Гуманитарный центр, 332 с.

Malanowski, J. R., \& Wood, P. H. (1984). Burnout and self-actualization in public school teachers. The Journal of Psychology, 117(1); 23-26.

Maslach, C. M. (2003). Job burnout: new directions in research and intervention. Current Directions in Psychological Science, 12 (5); 189-192.

Maslach C., Schaufeli W.B., Leiter M.P. (2001). Job Burnout, Annual Review of Psychology, 52 (1); 397-422

Маслоу А. (1999). Мотивация и личность / А. Маслоу. - СПб. : Изд-во "Евразия", 479 с.

Орёл, В.Е. (2005). Синдром психического выгорания личности. М.: Изд-во Института психологии РАН, 330 с.

Роджерс, К.Р. (1994). Взгляд на психотерапию. Становление человека / К.Р. Роджерс. - М.: Изд-во "Прогресс", 480 c. 
Ронгинская, Т.И. (2002). Синдром выгорания в социальных профессиях / Т.И. Ронгинская // Психологический журнал. Т. 23. №3. С. 85-95.

Shirom A. (1989). Burnout in work organizations, Cooper C.I., I. Robertson. International Review of Industrial and Organizational Psychology, pp.25-48

Skaalvik, E. M., \& Skaalvik S. (2015). Job satisfaction, stress and coping strategies in the teaching profession - What do teachers say? International Education Studies, 8(3); 181-192.

Freudenberger, H.J. (1974). Staff burnout. Journal of Social Issues, 30(1); 159-165

Folkman, S. (2013). Stress: Appraisal and coping In Gellman M. D., editor. (Ed.), Encyclopedia of behavioral medicine (pp. 1913-1915). New York, NY: Springer.

Форманюк, Т.В. Синдром эмоционального сгорания как показатель профессиональной дезадаптации учителя // Вопросы психологии. - 1994. - № 6. - С. 57-63 